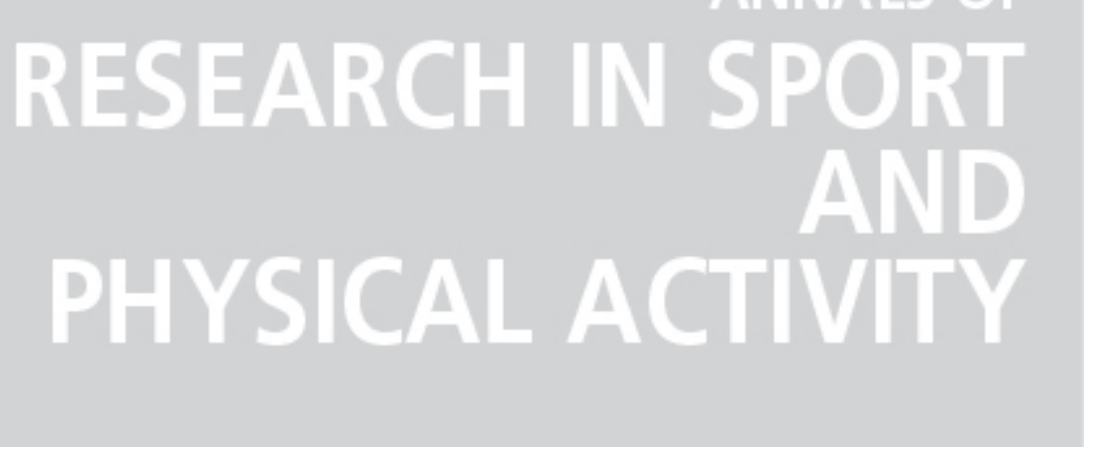

Mucosal immune markers in professional English football players

Autor(es): $\quad$ Hynes, Eleanor; Davison, Glen

Publicado por: Imprensa da Universidade de Coimbra

URL

persistente: URI:http://hdl.handle.net/10316.2/44126

DOI: DOI:https://doi.org/10.14195/2182-7087_ex2018_62

Accessed : $\quad$ 26-Apr-2023 11:15:20

A navegação consulta e descarregamento dos títulos inseridos nas Bibliotecas Digitais UC Digitalis, UC Pombalina e UC Impactum, pressupõem a aceitação plena e sem reservas dos Termos e Condições de Uso destas Bibliotecas Digitais, disponíveis em https://digitalis.uc.pt/pt-pt/termos.

Conforme exposto nos referidos Termos e Condições de Uso, o descarregamento de títulos de acesso restrito requer uma licença válida de autorização devendo o utilizador aceder ao(s) documento(s) a partir de um endereço de IP da instituição detentora da supramencionada licença.

Ao utilizador é apenas permitido o descarregamento para uso pessoal, pelo que o emprego do(s) título(s) descarregado(s) para outro fim, designadamente comercial, carece de autorização do respetivo autor ou editor da obra.

Na medida em que todas as obras da UC Digitalis se encontram protegidas pelo Código do Direito de Autor e Direitos Conexos e demais legislação aplicável, toda a cópia, parcial ou total, deste documento, nos casos em que é legalmente admitida, deverá conter ou fazer-se acompanhar por este aviso. 


\section{ANNALS OF RESEARCH IN SPORT AND PHYSICAL ACTIVITY}




\title{
MUCOSAL IMMUNE MARKERS IN PROFESSIONAL ENGLISH FOOTBALL PLAYERS.
}

\author{
Eleanor Hynes ${ }^{11}$; Glen Davison ${ }^{1}$
}

KEYWORDS: immunoglobulin A; football; illness; monitoring.

Team sport athletes appear to be more susceptible than normal to infection, especially upper respiratory tract infections (URTI) (i.e. coughs, sore throat, runny nose etc), during periods of intensified training and match play ${ }^{(1)}$. A decrease in individual relative concentration of salivary immunoglobulin A (s-IgA) has been shown to be associated with an increased risk of URTI(2). The objective was to examine the relationship between s-IgA and upper respiratory illness during a period of intensive match play (fixtures) in a group of professional English football players. Following University ethics approval, 16 male footballers from a professional English League 1 club provided unstimulated saliva samples on the same morning of each week for 16 weeks. Upper respiratory illness symptoms were recorded on a questionnaire. Saliva samples were analysed for s-IgA concentration and secretion rate. Individual healthy baseline s-IgA was calculated as the average across all weeks when no illness symptoms were present. Data are expressed as mean \pm SEM. Over the 16-week study period, 238 saliva samples were collected and analysed. Mean s-lgA concentration was $127 \pm 5 \mathrm{mg} \mathrm{L}^{-1}$ with a mean CV of $53 \%$, between individuals CV was $62 \%$. Mean s- IgA secretion rate was $60 \pm 1 \mathrm{mg}^{-1 \mathrm{~m}^{-1}}$ with a mean CV of $57 \%$, between CV was $69 \%$. Two individual illness episodes occurred during the 16-week period, both when s-IgA was lower than $40 \%$ individual healthy baseline, with symptoms lasting 4-7 days. s-IgA concentration and secretion rate were highly variable within and between individuals. s-IgA decreased following a period of intensified competitive match play to $40-70 \%$ of each individual players' healthy baseline. A decrease in s-IgA below $40 \%$ of healthy baseline would suggest an increased risk of infection however not all periods of low s-IgA resulted in illness symptoms. Furthermore, just two illness episodes occurring during the monitoring period so it is not possible to confirm a link between s-IgA values (as absolute values or \% of healthy base-

\footnotetext{
1 University of Kent.

Email: eh361@kent.ac.uk
} 
line) and illness incidence. Whole squad s-IgA increased as the number of days between competitive matches increased (i.e. no midweek matches). Based on these results coaching staff could consider the amount of recovery time given to players during intensified periods as factors such as time spent travelling, and disruption to sleep and nutritional routines alongside increased competitive workload may be responsible for suppression of immunity.

\section{REFERENCES}

1. Cunniffe, B., Griffiths, H., Proctor, W., Davies, B., Baker, JS. and Jones, KP. 2011, Medicine and Science in Sports and Exercise, 43, 388-397.

2. Neville, V., Gleeson, M. and Folland, JP. 2008. Salivary IgA as a risk factor for upper respiratory infections in elite athletes. Medicine and Science in Sports and Exercise, 40, 228-1236. 